\title{
IUELTAL
}

\section{The Inclusion of Sociolinguistic Context in the Text Materials of English Text Books for Junior High School}

\author{
Endang Susilawati \\ FKIP Universitas Tanjungpura Pontianak \\ e-mail: endang.susilawati@fkip.untan.ac.id
}

\begin{abstract}
:
This research is conducted for two main objectives, (1) to identify whether the sociolinguistic contexts have been included in the presentation of interpersonal and transactional text materials in the selected textbook; (2) to analyze the variables of contexts that might have been included. The text book being analysed is an English textbook for Grade VII, "The title is Bahasa Inggris When English Rings a Bell, SMP/MTs Kelas VII, which is written by Siti Wachidah, Asep Gunawan, Diyantari, Yuli Rulani Khatimah. It is reviewed and edited by Rd. Safrina Noorman and Lestari Manggong and published in 2017 by Pusat Kurikulum dan Perbukuan, Balitbang, Kemendikbud. This research is an evaluation research by applying content analysis method. The analysis is started by (1) identifying or codifying the text materials which belong to both interactional and transactional conversation; (2) categorizing the types of conversations (interactional or transactional); (3) analyzing the inclusion of sociolinguistic contexts in each of the conversations based on the four out of five variables of sociolinguistic contexts proposed by Harmer (2001). The variables include setting, participant, channel, and topic; the last (4)interpreting the result of analysis. The findings show that almost all the topics of the dialog texts have been designed concurrently with the English syllabus for SMP/MTs Kelas VII. Yet, there are only few variables of setting, participant, and channel which are identifiable. To conclude, the variables of sociolinguistic contexts have not been entirely included in the text materials.
\end{abstract}

Key words: sociolinguistic contexts, sociolinguistic competence, text materials

\section{Introduction}

Communicative competence should be the termination of a second language teaching and learning. It is represented by the acquisition of sub-communicative competences namely linguistic or grammatical, sociolinguistic, discourse and strategic competencies (Savignon, 
2002, Street \& Leung, 2010). Therefore, sociolinguistic competence should be represented in the learning materials in addition to the relevant language focuses used within the genre of texts being learned. The attainment of sociolinguistic competence will support the acquisition of thorough English communicative competence. Sociolinguistic competence implies the requirement of the inclusion of sociolinguistic contexts in the design of text materials and the language learning tasks. In addition, sociolinguistic competence implies the values of appropriacy or acceptability of language usage in terms of politeness, formality of the language style being used in the conversation. It should be as important as grammatical, discourse and strategic competences.

English text materials for formal school, such as for the junior high school in Indonesia, are normally provided in English textbooks. They should be designed in consistent with the curriculum implemented by the school. Currently, it is Curriculum 2013. Essentially, Curriculum 2013 for English language subject mandates an acquisition of both the knowledge of text types and the language features in integration with the achievement of the four language skills in the sosial interaction by the learners, as it is stated in the Basic Competences (Kompetensi Dasar 3 and Kompetensi Dasar 4 of the syllabus). Meanwhile, Nunan (2001) refers competencies as to be concerned with the attainment of specified standards rather than with an individual achievement in relation to a group. In short, curriculum 2013 implicitly recommends the achievement of English communicative competences at the end of the course.

Nevertheless, communicative competence is quite complex and comprehensive. They must be represented by comprehensive dimensions: fluency, accuracy, appropriacy and comprehensibility. The fluency and the accuracy are represented by the acquisition the grammatical competence while the appropriacy should be represented by the sociolinguistic competence and the discourse competence will be actualized from the learner's familiarity on various genres of texts. Thus, all the parts of the communicative competence should be developed thoroughly in balanced depending on the required level of the competence for the learners (Savignon, 2002).

By referring to the ideas mentioned above, this present study focuses on the issue of the inclusion of sociolinguistic context within the English text materials for Junior High School students. The conversation text materials which are characterized by the inclusion of sociolinguistic contexts are supposed to provide learners with learning experience to practice the use of English in real communication. Understanding the sociolinguistic context will support the actualization of sociolinguistic competence It is represented by understanding the roles of the participants, the information they share, and the function of the interaction (Saville-Troike, 2008). Understanding sociolinguistic context is very important for its implication to the awareness of the norm, appropriacy and variability in communication. In short, sociolinguistic competence is about probabilistic rules of occurence concerning whether something is 'sayable' in a given context (Street \& Leung, 2010, p.291). It also concerns the extent to which particular communicaive functions, attitudes (including politeness and formality), and such proper ideas in a given situation (Canale, 2014). For a language function of 'greeting', for example, a speaker should realize the context of whom he/she is greeting, what kind of social role-relationship they possess (whether they are in equal social status or stand, such as between friends, colleagues, siblings or they are in different social status, such as between a student and a teacher, a 
young and an elder and otherwise); in what setting the greeting is occurring (whether it is in a formal meeting or only an informal or intimate conversation).

In fact, communicative competence has been long to underlie the communicative language teaching (CLT). Since 1980s, it has become the principles of curriculum design of the second or foreign language teaching and learning, the teaching approach as well as the manifestation in teacher's handbooks, manuals, and the textbook writer. One of the principles for the curriculum and materials design is context- and participant-based. Instead of merely generating the teaching content of the target language system, it should firstly identify what and how language is used in the pre-specified domain of use (Street \& Leung, 2010).

Specifically, this study takes the genres of interpersonal and transactional communication texts within which the sociolinguistic contexts should be included as the focus of analysis. Interpersonal and transactional communication skills are supposed to be parts of the language competencies that must be acquired by the Junior High School learners. To cover these competencies, the relevant text materials presented should take the forms of authentic dialogues or conversations. Moreover, to be consistent with the principle of the context- and participant-based, the learning materials should not simply provide the examples of the list of the relevant language expressions or the linguistic forms occur in such interpersonal and transactional conversations. Instead, they would rather include the illustration of such context, as for example, the setting (when and where the conversations occur), the role-relationship between the speakers (who speak what to whom), the information they share, as well as the tone voice. Including various contexts means to introduce different variations of language use.

To such an extent, the relevant educational institution has facilitated the learners with such relevant text materials provided in the English textbooks for Junior High Schools (SMP). The textbooks are written by professional textbook writers which are sponsored by the government of Republic of Indonesia through its Ministry of Education and Culture (see Bahasa Inggris Kelas VII, VIII, IX. Edisi Revisi, Act Locally, 2017, 2018. by: Siti Wachidah, Asep Gunawan, Diyantari. Jakarta: Kementerian Pendidikan dan Kebudayaan Republik Indonesia). By skimming, it is identifiable that the textbook covers interpersonal communication texts with some language functions, such as greeting, leave taking, thanking, apologizing, introducing oneself or others, and so forth. It also covers transactional communication texts with a number of language functions which consist of telling time, day and date, describing, identifiying and criticizing someone, an object, a place or a situation, and some more.

However, after scanning and reading the contents of the texts more intensively, it is found that they seem to only cover the examples of dialogues or conversations and the lists of language focus related to the topics and the language functions used in the dialogues. Meanwhile, the aforementioned sociolinguistic contexts seem still to be ignored. Since the exposure of the sociolinguistic context of a conversation is required in addition to the language focus and contents to support the acquisition of the communicative competence thoroughly, it becomes crucial to do in-depth evaluation on the textbooks. The findings are expected to reconfirm whether or not the sociolinguistic contexts have been included in the text materials development. For this reason, then, this research is conducted. 
In fact, evaluation studies on the contents of English textbooks are quite fruitful from either the context of foreign countries or Indonesia. Mostly their analysis are for the purpose of evaluating the textbooks for their standard contents and their suitability to the curriculum references as well as the fitness to the learners' need (see Guilloteaux (2013), Reinildis Atjna Cyntia Rynanta (2018), Fatima \& Kazim Shah (2015), Fuyudloturromaniyyah (2015), Akbar (2016), Suryani (2018), Dharma \& Aristo (2018), Tambunan et al., (2019), Nurjanah \& Umaemah (2019)). Despite taking various kinds of English textbooks with various theoretical frameworks to refer to, almost all the studies have similarities on their purposes and research methodology. Besides, they mostly end up with the recommendation on the textbook revision. From the review of those previous studies, the present research should be distinctive for its objectives and the perspective underlying the theoretical framework. It is about the text materials design to deal with the theory of communicative competence and sociolinguistic competence for particular.

To summarize, the review of those previous researches implies the reconfirmation of the need to conduct the present study for its different objectives as well as the theoretical underpinnings. It will contribute additional theoretical framework for further textbook evaluation research. Moreover, the findings will become the constructive criticism towards the text materials design of the textbooks, especially when it is viewed from the sociolinguistics perspective. However, referring to the research methodologies applied in the former researches, they can be adopted as models to refer to by the present study.

From such a background, this research is conducted for the following objectives (1) to identify whether or not the sociolinguistic contexts have been included in the presentation of interpersonal and transactional text materials provided in the selected textbook; (2) to analyze the variables of contexts that might have been included. Since it is an evaluation research, the findings should be a beneficial feedback for either the English teachers or the textbook designers/writers. Such findings should conceive the urgency of doing further research, especially the development research.

\section{Literature Review}

\subsection{Sociolinguistics Issues and Communicative Language Teaching}

With reference to the review of the previous researches above, the present research is taking different theoretical framework. It refers to the notions of foreign language teaching and learning from sociolinguistics perspective. Sociolinguistics is familiar among scholars of linguistcs, sociology and anthropology. It is the field that studies the relation between language and sociaty, between the uses of language and the social structures of the users (Spolsky, 2010). Sociolinguists are interested in explaining why we speak differently in different social contexts, and they are concerned with identifying the social functions of language and the ways it is used to convey social meaning (Holmes, 2013). In the last few decades it has devoted a big contribution to the development of language teaching and learning theories. Subsequently, the later discussions of language teaching and learning theories are always associated with sociolinguistic concepts.

It was formerly started by Hymes in 1960 s who dedicated his work on ethnography of speaking or ethnography of communication with a very influential notion called communicative competence (Street \& Leung, 2010). He had reacted to Chomsky's 
characterization of the linguistic competence of the ideal native speaker and proposed the term communicative competence to represent the use of language in social context, or the observance of sociolinguistic norms of appropriacy which is potentially equiavalent to what functionalists mean by meaning (Halliday, 1996).

The concept of communicative competence has changed the view of language teaching methodology from traditionally engaging learners to practice communication in lies of laboratory pattern drills performed with no less accuracy on discrete point tests of grammatical structure to developing learner's ability to actually use the language for communication by which the focus is on meaning as opposed to form (Savignon, 2002). This view has generated a relatively new language teaching approach called communicative language teaching (CLT). It views language as a system for expressing meaning. The primary function is interaction. The theory of learning is based on the belief that activities involving real communication; carrying out meaningful tasks and using language that is meaningful to the learner promote learning (Nunan and Lamb, 2013). In addition, Savignon explains that CLT is derived from a multidiciplinary perspective that includes, at a minimum linguistics, psychology, philosophy, sociology, and educational research..

The essence of CLT is the engagement of learners in communication in order to allow them to develop their communicative competence. The features include process oriented, task based, and inductive, or discovery oriented. However, CLT is not exclusively concerned with face to face oral communication. The principles of CLT apply equally to reading and writing activities that involve readers and writers engage in the interpretation, expression, and negotiation of meaning; the goals of CLT depend on the learner need in a given context. In keeping with the notion of context of situation, CLT is properly seen as an approach or theory of intercultural communicative competence to be used in developing materials and methods appropriate to a given context of learning (Savignon, 2002) and the primary role of materials is for promoting communicative language use.

\subsection{Communicative Competence and Sociolinguistic Competence}

In general, communicative competence is the desired goal of CLT. Likewise, it is in agreement with the standard competence required by curriculum 2013. From the ethnography of communication point of view, communicative competence refers to the communicative knowledge and skills shared by a speech community, but these (like all aspects of culture) reside variably in its individual members. The shared yet individual nature of competence reflects the nature of language itself (Saville-Troike, 2008). For Hymes (1972) a communicative competence of a language is acquired when a child acquired knowledge of sentences, not only as grammatical, but also as appropriate. He or she will realize when to speak, when not, and as to what to talk about with whom, when, in what manner. In other words, there are social rules of use, a dimension of language use without which the rule of grammar would be useless. The notion of competence here implies the importance of the actual use of language in context (Hymes, 1972, p. 277-278). In short, communicative competence should represents the use of language in social context, or the observance of sociolinguistic norms of appropriacy (Savignon, 2002).

From the perspective of foreign or additional language pedagogy, communicative competence comprises four areas of knowledge and skills (Canale and Swain in Street \& Leung, 2010). They include: (1) grammatical competence. It is concerned with knowledge of 
lexical items, and rules of morphology, syntax, sentence grammar semantics, and phonology; (2) sociolinguistc competence, this competence deals with rules of use. It requires an understanding of social context in which language is used: the roles of the participants, the information they share, and the function of the interaction (Savignon, 2002). In other words, it addresses the extent to which utterances are produced and understood appropriately in different sociolinguistic contexts. Appropriateness of utterances refers to several concerns such as the extent to which particular communicative functions (e.g. commanding, complaining, and in inviting), attitudes (including politeness and formality), and proper ideas for such a given situation; (3) discourse competence, it is concerned with the organizational features of spoken and written texts. It refers to what is recognized as the text cohesion and coherence; and the last is (4) strategic competence, it refers to additional language learner's capacity to achieve communication goals by mastery of verbal and nonverbal communication strategies. In short, comunicative competence is characterized by the ability of classroom language learners to interact with other speakers, to make meaning, as distinct from their ability to recite dialogs or perform on descretepoint test of grammatical knowledge. Its dimension should be be indicated by fluency, comprehensibility, accuracy and appropriacy or appropriateness.

It is obvious that communicative competence does not merely include knowing the language code, but also the what to say to whom, and when to say it appropriately in such a given situation (Saville-Troike, 2009). Appropriateness here refers to whether and to what extent the language code is suitable with the context. Having knowledge of appropriateness will represent the speaker's sociolinguistic competence. That is why it is necessary to expose a language learner with models of appropriate use of the language based on the context in addition to its fluency and accuracy. Sociolinguistic competence is represented by variety usage of the language to match the context within which the language is used. To study the context means to adjust the way we speak or write following the non-linguistic factors. They refer to the circumstances and conditions relevant to a particular action, event or fact. Understanding context is important due to the fact that in daily speech people speak to different people, in different situations, for different purposes, such as to talk to friends, family members, to participate in an official meeting, to do shopping and many more. In such various situations they will not use the same language variation. They would rather adjust the use of their vocabulary, phrases, grammar, pronunciation and the level of formality to make their speech appropriate to such a context. (Davies, 2014).

Therefore, sociolinguistic competence of English language should start by exposing the language learners with varieties of English which might include standard language, dialects, registers, styles, oral and written language as their communicative repertoire. Likewise, the varieties may include different occupational codes, specialized religious language, secret codes of various kinds, imitative speech, whistle or drum language, and varieties used for talking to foreigners, young children and pets (see Holmes, 2013; Saville-Troike, 2008; Wardhaugh, 2006). In addition, exemplifying variations of the language code based on its purposes or functions should be recommended as well. For examples, the language of email, short messages, the language used in social media, and so forth (Davies, 2014). By introducing those language variations, the learners will be simultaneously exposed to various contexts and different purposes of such language uses. For the interpersonal and transactional kind of communication, particularly, the context should deal with the setting 
whereby the dialogs or the conversations occur, the roles of the participants involved in the conversations as well as the topics and the purposes or the functions of the conversations. The details are explained in the next sub-headings.

To gain such a communicative competence, especially the sociolinguistic competence, the learners should be facilitated with such learning materials. In this case, the exposure to the relevant authentic materials by which the real use of English language usually occurs is recommended. Accordingly, the learning materials should engage the learners with classroom activities that are characterized by CLT. By referring to the topics and the language functions for interpersonal and transactional communication recommended by curriculum 2013, various sociolinguistic contexts and the relevant use of such language variation should consistently be included in the materials design.

\subsection{Interpersonal and Transactional Communication and The Material Manifestation}

Curriculum 2013 mandates the teaching of interpersonal and transactional communication to junior high school learners. Interpersonal and transactional communication expose the learner to the real basic communication occurs in daily life. Interpersonal communication is also recognized as interactional communication or interactional speech. It is carried out more for the pupose of establishing and maintaining social relationship than for transmission of facts and information. It includes greetings, compliments, telling jokes, and making casual conversation or chat. Meanwhile, transactional communication is carried out for the purpose of conveying or exchanging specific information, such as buying and selling, instructing, describing, and so on (Corbett, 2003). It is an extended form of responsive language. It involves communicating to get something done, including the exchange of goods and/or services (Brown, 2007; Bailey, 2005).

Both kinds of communication occur in the form of daily conversations or dialogs. They may occur once at a time in a daily conversation, starting from the interpersonal communication with its social function and then moving along with an informative or referential function in the transactional communication (Holmes, 2001). More than one active participant should be involved in the communication. Furthermore, Nunan (1991) stated that interactional speech is more flued and relatively unpredictable compared to transactional speech. It can range over many topics with the participants taking turns and commenting freely. Whereas transactional speech is more fairly restricted kind which usually contains highly predictable patterns. With regard to this, Nunan suggested that the speaking activities inside the classroom need to embody both interactional and transactional settings (in (Bailey, 2005) as for it is similarly required by curriculum 2013.

In addition, Brown elaborated that conversations in transactional speech may have more of a negotiative nature to them than merely responsive speech, as it occurs in an example of the following conversation:

$\mathrm{T}:$ What is the main idea in this essay?

$S$ : The United Nation should have more authority.

$\mathrm{T}$ : More authority than what?

$S$ : Than it does right now.

$\mathrm{T}$ : What do you mean?

$S$ : Well, for example, the UN should have the power to force a country like Iraq to destroy its nuclear weapons. 
T: You don't think the UN has that power now

$\mathrm{S}$ : obviously not. Irac is still manufacturing nuclear boms

In contrast, interactional or interpesonal conversations are carried out for more maintaining social relationship than for the transmission of facts and information. Therefore, they can involve some or all of the following factors: casual register, colloquial language, emotionally charged language, slang, ellipis, sarcasm, a covert 'agenda', for example:

Amy : Hi, Bob, how is it going?

Bob : Oh, so-so.

Amy : Not a great week end, huh?

Bob : Well, far be it from me to critisize, but I'm pretty miffed about last week.

Amy : What are you talking about?

Bob : I think you know perfectly well what I'm talking about....

(see Brown, 2007)

In consideration with the characteristics of both interpersonal and transactional conversations and to be consistent with the view of CLT as well as the notion of communicative competence, especially the sociolinguistic competence, the learning materials should be menifested accordingly. In other words, learners should be facilitated by such conversational text materials as an attempt to acquire the learning goal, the English communicative competence. Take for example, the conversation of greeting and introduction in interactional speech should be presented in the form of dialog models with various settings (at least formal and informal). They might involve different rolerelationship of the participants (e.g. teacher-student, between friends, between two persons who only meet for the first time, parents-children, between two professionals and so forth) as well as the variety of language expressions with their appropriate choise in consistency with the formality and politeness. Here are the models of the conversations:

\section{Model 1}

It is between teacher and student in the classroom

T : Good morning, students? I'm Arini Mulia. I'm your new English teacher. You can call me Miss Arini.

$\mathrm{S}$ : Good morning Miss Arini.

$\mathrm{T}$ : How are you this morning?

$\mathrm{S}$ : We're fine, thank you, Miss Arini.

\section{Model 2}

It is between two closed friends or schoolmates and a new friend somewhere in the school area.

Mirna : Hi, Dora. How are you doing?

Dora : Hi, Mina. I'm good.

Mirna : Oh ya Dora, this is Syifa, my cousin from Bandung. She is our classmate now. Dora : Oh, really? Great to see you Syifa. My name's Dora. Welcome to our school. Syifa : Thanks Dora. I'm glad to see you, too.

\section{Model 3}


It is between two persons with almost the same age, who meet each other for the first time at the neighbouhood.

$\mathrm{P}_{1}$ : Excuse, me. Are you Adam?

$P_{2}$ : No, I'm David.

$\mathrm{P}_{1}$ : Oh, I'm sorry, David. My name's Ricky. I'm your new neighbour.

$\mathrm{P}_{2}$ : Oh, nice to meet you Ricky.

$P_{1}$ : Nice to meet you, too.

From the conversations above, it shows that each conversation model has different sociolinguistic contexts which will ultimately affect the appropriate use of expressions or language choice. Therefore, the contexts are very important to be exposed to the learners in order to make them aware of appropriacy dimension in addition to accuracy of the language use. To realize the appropriate use of certain language forms or expressions, Harmer (2001) suggested five variables which govern the choise. They are:

(1) Setting: It refers to the place and the situation (formal or informal) where the conversation is taking place, for example, at home, at school, at an office or work environment.

(2) Participants: the people involved in an exchange and the social status or the rolerelationship between or among them, whether they are in equal status or probably one is superior over the other. For example, between closed friends, new acquaitance, teacher-student, family members, colleagues, buyer-seller, and other social relationship.

(3) Gender: research clearly shows that men and women typically use language differently when addressing either members of the same or the opposite sex. Women have frequently used conversation more conceive language than men, for axample, and crucially, have often talked less than men in mixed-sex conversations .

(4) Channels: It deals with spoken or written language. For spoken language, particularly, it might be differenciated whether it is face-to-face or via other channel like telephone or other media.

(5) Topic: the topic we are addressing affects our lexical and grammatical choices.

What Harmer proposed above is basically along the line with the idea of imposing language use in social context, or the observance of sociolinguistic norms of appropriacy by which sociolinguistc competence will be represented. It is the competence which deals with rules of use, that is by understanding of social context in which language is used. They include the roles of the participants, the information they share, and the function of the interaction (Savignon, 2001). To sum up, more conversation models with various sociolinguistic contexts should be provided in the textbooks for practicing the interactional and transactional communication. By then, the learners will be exposed to learn appropriate use of language in addition to fluency practice as well as the language accuracy as they are requirements of communactive competence goal achievement. 


\section{Research Methodology}

\subsection{Research Objects}

To be consistence with the research objectives, this research belongs to 'evaluation research' (Vockell \& Asher, 1989; Mertens, 2014). The research object is an educational product in term of English textbook for students of Junior High School. The Ministery of Education and Culture Republic of Indonesia has enforced the English teachers to use those texbooks as the compulsory one in their teaching. In fact, there are three series of English texbooks mandated to be used by English teachers of Junior High School by the institution. Those are for grade VII, VIII and grade IX. However, due to some restrictions encountered throughout the research processing, especially the time constraint, only textbook for grade VII is manageable to be analysed in this study, "Bahasa Inggris When English Rings a Bell, SMP/MTs Kelas VII", which is written by Siti Wachidah, et al. and reviewed/edited by Rd. Safrina Noorman and Lestari Manggong. It is published by Pusat Kurikulum dan Perbukuan, Balitbang, Kemendikbud (2017).

\subsection{Technique of Data Collection}

The main data of this research is the contents of the text matrials written in the selected texbooks. So it belongs to content analysis research which is closely to both interpretative analysis and conversation analysis (Nevendorf, 2017). The contents of the textbooks being analyzed are the texts which are categorized as interpersonal and transactional dialogues or conversations. These two types of text are chosen because the language use within the texts should be ruled accordingly to the sociolinguistic contexts. Furthermore, the components or the variables of the sociolinguistic contexts are analyzed through four stages as they are described in the data analysis procedure below.

\subsection{Data Analysis Procedures}

To be consistent with the research questions as well as the research purposes, the contents which were selected to be the units of analysis should be delimited. Therefore, the conversations or the text materials being selected from the first series of the textbooks mentioned above were limited to those belong to interactional and transactional communication, especially the conversations provided as input models.

In analyzing the contents of the textbooks, two raters were employed. One is the researcher herself and the other is a representation of experienced English teachers from this school level. Two raters are required to maintain the consistency and the objectivity of the categorization as well as the interpretation process within the evaluation process.

The variables of sociolinguistic context being analyzed are based on those proposed by Harmer (2001). They include setting, participants, channel, and topics. These five variables will regulate the appropriate language use in interpersonal and transactional conversation or dialog. The analysis is started by (1) identifying or codifying the text materials which deal with both interactional and transactional conversation; (2) categorizing which conversations belong to interactional and which ones belong to transactional; (3) analyzing the inclusion of sociolinguistic context in each of the conversations; (4) the interpretation of data analysis. Tabulating is considered the most suitable kind of data display. For the sake of efficiency and leniency for such analysis process, certain symbols or markers are purposely created for each variable being analysed. Therefore, several codes of abbreviation are made 
for the simplification of codifying, such as the use of TS refers to transactional dialog and IP refers to interpersonal dialog (found in another table), O-DFTF refers to the dialog which is in direct face-to-face oral communication.

The analysis process from step 1 to 3 are done by the two raters. After that, rater 1 compares the result of her rating to the result of rater 2 to test the consistency or reliability. For the last step, the data interpretation, is only executed by the first rater (rater 1). However, for any necessary reconfirmation on the final data analysis are made together by the two raters. The table below (table 2 ) represents how the steps of data analysis are being processed by both raters.

Table 1: The Content Analysis of Chapter III

\begin{tabular}{|c|c|c|c|c|c|c|}
\hline \multirow{2}{*}{$\begin{array}{c}\text { Chapter } \\
\text { (Page No - } \\
\text { Dialogue } \\
\text { No) }\end{array}$} & \multirow{2}{*}{$\begin{array}{l}\text { Dialog } \\
\text { Type }\end{array}$} & \multicolumn{4}{|c|}{ Sociolinguistic Context } & \multirow[t]{2}{*}{ Remark } \\
\hline & & $\begin{array}{l}\text { Topic } \\
\text { (function) }\end{array}$ & Setting & $\begin{array}{l}\text { Participant } \\
\text { (Role Rel.) }\end{array}$ & Channel & \\
\hline III (44)-D30 & TS & $\begin{array}{l}\text { telling time, } \\
\text { date and day }\end{array}$ & $\begin{array}{l}\text { unclear } \\
\text { defined }\end{array}$ & $\begin{array}{l}\text { between } \\
\text { friends }\end{array}$ & O-DFTF & Unidentified \\
\hline
\end{tabular}

\section{4. $\quad$ Findings}

As the reminder, the variables of the sociolinguistic contexts are categorized by following the four of five variables introduced by Harmer, (2001), which include setting, participants, channel, and topics. The contents being analyzed are the whole dialogs of interpersonal and transactional communication that are encountered in the selected textbook. The analysis is done respectively chapter by chapter from the textbook and displayed in tables. Completely, the identity of the textbook is written below.

English Textbook for Grade VII

Title: When English Rings a Bell Kelas VII SMP/MTS

The writers: Siti Wachidah, Asep Gunawan, Diyantari, Yuli Rulani Khatimah

Reviewers/editor: Rd. Safrina Noorman dan Lestari Manggon

Publisher: $\quad$ Pusat Kurikulum dan Perbukuan, Balitbang, Kemendikbud. (2017)

Contents: 8 chapters

Number of dialogs: 69 dialogs of interpersonal (IP) and transactional (TS) communication

From the content analysis of chapter 1 it is noticeable that all the dialogues belong to interpesonal communication. The main topics are dealing with the language functions: 'greeting', 'leave taking', 'thanking' and 'apologizing'. Meanwhile, for the sociolinguistic context point of view, it is found that only variable of topic which consistently represent the whole number of conversations or dialogs in chapter 1 . Unfortunately, the settings of the conversations are not totally exposed. In this case, there are only eight (8) conversations out of 27 without setting representation. Moreover, the setting is dominated by the school setting. There are three conversations which have home setting while the rest are unidentified. With regard to the role-relationship of the participants, there are three conversations which are with unidentified participant's role relationship while the rest of the conversations are dominated by teacher-student and student-student role-relationship. Both the available setting and the role-relationship are only identified by pictures. From the 
channel, it is notified that the conversations are all supposed to be face to face conversations with oral or spoken as the choice of language. The variety of language usage following the range of formality or social distance factors is not yet taken into consideration. The choice of certain dialog practices even sound unnatural and absurd illogical, such as the one found in dialog 12 (p7).

Son: Good evening, Dad. Are you tired?

Father: Good evening Beni. Yes, I'm tired. I wan to take a bath and then have dinner.

From chapter II, it is found that the dialogs are classified as transactional communication. The topics are about "sharing \& enquiring each other's identity" which is relevant to the topic of the chapter (chapter II). That is "talking about our identity, hobby and family". Unfortunately, the setting is unidentified at all. The role-relationship of the speakers is only identified from the pictures that is from the clothes they are wearing. They show that they have teacher-student role-relationship. Meanwhile, the channel does not indicate various choice of language use. It is only dominated by single kind of face to face oral or spoken language.

Meanwhile, based on the conversation encountered in chapter III, it is notified that there is only one conversation. It belongs to transactional communication. The topic is about "telling time, date and day". The role-relationship between the speakers is identified as between friends while the setting is not clearly defined. The channel does not indicate various choice of language use, either, as it does not occur in the previous dialogs. It is only dominated by single kind of face to face oral or spoken language.

Since chapter IV does not provide any dialogue text, the analysis was skipped to chapter V. from this chapter it is found that there 27 dialogs being presented. They all belong to transactional communication. It is found that several conversations are not consistent with the topics mentioned in the chapter heading, especially the dialogs on page $32,34-36 ; 39$ 40; and page 57. In the meantime, there are only two dialogs that are exposed with clear settings while the rests are not. Moreover, the role-relationship being exposed is only monotoneous, that is only between friends. Such monotoneous model also occurs in channel variable, that is face to face oral communication with single choice of language variety, the neutral expressions.

Furthermore, chapter VI only presents eight (8) dialogs. They all belong to transactional conversations with various topics and language functions, such as "asking and giving information about what parents' job, what we do, everyday activities"; "inviting someone"; "talking about nature"; and "telling about the quality of an animal". Varieties of setting appear in terms of home, school or classroom. Unfortunately, one dialog is without clear setting. The role-relationship of the participants in the dialogs are only limited to teacherstudent and between friends while the channel still remains the same as they are found in the former chapters, that is direct face-to-face oral communication.

The last, from chapter VII, it is found that there are four transactional dialogs with various topics, such as: 'asking where a thing is and describing thing (a notebook)'; 'describing and finding a place'; 'describing and finding something'; and 'offering something'. Nevertheless, almost all the topics are not consistent with the topic mentioned in the chapter, that is 'I'm proud of Indonesia' with the language functions: 'to make them stand out', 'to show my 
pride of them', 'to promote them', and 'to critisize them'. All the dialogs are with undefined setting and the partticipants are all between friends (colleagues) role-relationship. Meanwhile, direct face-to-face oral communication is the only kind of channel practiced in all those conversations.

Based on the description above it can be identified that the total dialogs provided in all chapters of the textbook are 68 dialogs. They consists of 27 interpersonal and 41 transactional communication dialogs. Several topics (10 topics out of 68 ) are not relevant with the topics mentioned in the chapter's headings as they are all remarked in chapter VII and some in other chapters. With regard to the setting exposure, there are only 34 dialogs (50\%) are exposed with their clear settings while the other $50 \%$ are without identified settings. Besides, the settings are dominated by the classroom or school setting. The illustration of the settings is only identified by the pictures drawn within the dialogs.

The participants involved in the dialogs are dominated by between friends and followed by teacher-student(s) role-realationship. In addittion, parents-children role-reationship represents several dialogs and there is no dialog reperesenting other category of rolerelationship. Moreover, the channel is only represented by only single mode, that is direct face to face communication. As a result, the exposure of various language expressions used in the dialogs are not provided. In other words, the usage of language varieties based on various context is not yet exposed in the dialogs.

\section{Discussion}

Based on the findings, the contents of the textbook can be discussed from several point of views based on the aim of the research. In the case of the numbers and the types of the dialogs being provided, the textbook has exposed sufficient numbers of dialogs which cover both interpersonal and transactional dialogs, the very basic kind of oral communication which are commonly practiced in daily conversations. It is then appropriate to introduce them to junior high school students who are in the novice level. Thus, in terms of the content materials, the textbook has already fulfilled the teaching contents commanded by curriculum 2013. In addition, it reconfirms what Nunan (in Bailey, 2005) has suggested that the speaking activities inside the classroom need to embody both interactional and transactional settings. If the case is only deal with the adequate number of contents and the inclusion of dialogue types according to their communicative functions based on the curriculum mandate, there is no problem with the dialog texts found in the textbook, because they have been synchronized with the curriculum. This part of findings reconfirmed the most similar cases to those which have been earlier proven by Guilloteaux (2013), Rynanta (2018), Fatima \& Kazim Shah (2015), Fuyudloturromaniyyah (2015), Akbar (2016), Suryani (2018), Dharma \& Aristo (2018), Tambunan et al. (2019), and Nurjanah \& Umaemah (2019)

Nevertheless, the dialogues provided in the textbook are not yet completed by sociolinguistic context. The setting is not clearly identified for all the dialogs. The existing setting is only dominated by single setting. It is classroom setting. As a result, it does not represent the student's real-life communication as a whole. They are not supported by the involvement of participants with various social-relationship, either. Since the classroom setting dominates the conversation, the role-relationship is only represented by that of students/friends role-relationship, some of teacher-student role-relationship, and few of 
parents-child(ren) role-relationship. Such conversationa models are not pertinent to the essence of an interpersonal communication which is carried out more for the pupose of establishing and maintaining social relationship than for transmission of facts and information as well as that of a transactional communication, which is carried out for the pupose of conveying or exchanging specific information, such as buying and selling, istructing, describing, and so on (Corbett, 2003). Moreover, a transactional communication should involve communicating to get something done, including the exchange of goods and/or services (Brown, 2007; Bailey, 2005).

In short, both interpersonal and transactional conversations need to be clarified by not only their clear setting but also the role-relationship between the participants involved in the conversations. Both the setting of the conversations and the role-relationship of participants will subsequently regulate the appropriate use of language or expression in such a given context. Unfortunately, the conversations or dialogs provided in the textbook have not been completed with such sociolinguistic context. Such text characteristics will not expose the learners with sociolinguistc competence which is required to support the achievement of their thorough communicative competence. They will not represent the rules of language use, such as the roles of the participants, the information they share, and the function of the interaction which are supposed to acquire (Savignon, 2002). In other words, appropriate use of language should be introduced in such dialogs to deal with the communicative functions, the aspects of manner or attitudes (politeness and formality), and ideas of whether the utterance is properly or not properly used based on the given sociolinguistic context.

With reference to Harmer's variables of sociolinguistic context (setting, participants, channels, and topics), it is proven that 50\% dialogs in the textbook are dominated by classroom or school setting while the other $50 \%$ are not even exposed with clear and representative settings. The participants who involve in the dialogs do not embody various kinds of role-relationship or social status. Since classroom is the dominant setting, the rolerelationship is subsequently dominanted by teacher-students and between students rolerelationship. The same thing happens to the channel. It is only represented by single mode, direct face-to-face oral communication without considering various use of codes or varieties. Accordingly, the choice of formal and informal form of language expressions is still disregarded. In other words, the channel represents the ignorance of the appropriateness dimension of the language use. Despite the consistency of the dialog topics to the curriculum demand, several contents of the dialogs are noted to be inconsistent with the topics mentioned in the chapter's headings.

To summarize, in addition to reconfirm the findings of the previous researches, the findings of this present study should contribute different perspective for a textbook evaluation sociolinguistic perspective - by which it is necessary to include sociolinguistic contexts in conversational text material design as it is the representation of appropriacy dimension. It should be as important as the fluency and accuracy dimension of communicative competence. Whereas, most of previous researches only consider the contents of the textbook for their suitability to the curriculum mandates, especially for their linguistic contents and the adequacy of the language skills as well as the consistency of learning activities. Unfortunately, the sociolinguistic contexts are not completely included yet in the text materials. The findings of this research emphasize the importance of sociolinguistic 
context inclusion in English text materials to actualize the sociolinguistic competence, which will eventually contribute to the accomplishment of communicative competence at the end of the course.

\section{Conclusion}

Based on the research findings, it is concluded that all the topics of the interpersonal and the transactional dialogues are in consistent with those recommended by the syllabus of curriculum 2013. Yet, the sociolinguistic contexts which are supposed to indicate the setting of dialogs and to show the role-relationship between or among the participants involved in the dialog have not been entirely included. Besides, the dialog channel is only represented by single mode - direct face-to-face communication. It causes the absence of exposure to varieties of codes or varieties of choices with reference to the appropriate settings and the role-relationship of the participants involved in the dialogs. The existed settings of the dialogs are dominated by school or classroom setting and several others are home setting. In other words, the sociolinguistic contexts are not yet included in the text materials design. Therefore, the text materials can not exemplify the variation of language use in accordance with their sociolinguistic context.

Based on the conclusion, there are some points of recommendation for the textbook writers or designer. Firstly, the textbook should be redesign. Despite being consistent with the topics recommended by to curriculum 2013, the dialog texts should be designed by taking the sociolinguistic contexts into consideration. Secondly, the settings and the participants appearance should be represented by attractive illustrations, such as interesting images from the real colourful pictures or photos instead of cartoons. Thirdly, both the language activities and assessment provided in the textbook should be made consistent and relevant to comprehensive dimensions of speaking practices. In other words, they should include fluency, accuracy and appropriacy, as well as comprenensibility. Lastly, for further research, a development research on the textbook redesign should be appropriate to recommend. By including the sociolinguistic contexts in the textbook redesigning, it will facilitate the learners to acquire the comprehensive English communicative competence.

\section{References}

Akbar, R. (2016). An Analysis Of Selected Eleventh Grade English Textbooks. Journal Of English And Education.

Bailey, K. M. (2005). Practical English Language Teaching: Speaking. Mcgraw-Hill ESL/ELT. https://doi.org/10.1021/Acs.Joc.6boo331

Brown, H. D. (2007). Teaching By Principles, Second Edition. In Teaching By Principles An Interactive Approach To Language Pedagogy.

Corbett, J. (2003). An Intercultural Approach To English Language Teaching. In An Intercultural Approach To English Language Teaching. https://doi.org/10.21832/9781853596858

Cortezzi, M., \& Jin, L. (1999). Cultural Mirrors: Materials And Methods In The EFL Clasroom. In Culture In Second Language Teaching And Learning.

Davies, D. (2014). Varieties Of Modern English: An Introduction. In Varieties Of Modern English: An Introduction. https://doi.org/10.4324/9781315838861

Dharma, Y. P., \& Aristo, T. J. V. (2018). An Analysis Of English Textbook Relevance To The 
2013 English Curriculum. Journal Of English Educational Study, 1(1), 24-33. http://Download.Garuda.Ristekdikti.Go.Id/Article.Php? Article=931402\&Val=14466\&Tit le=An Analysis Of Textbook Relevance To The 2013 English Curriculum

Fatima, G., \& Kazim Shah, S. (2015). Textbook Analysis And Evaluation Of 7 Th \& 8 Th Grade In Pakistani Context. International Journal Of English Language Teaching.

Fuyudloturromaniyyah, N. (2015). A Textbook Analysis: An In-Depth Analysis Of Activities In Scientific Approach's Perspective In An EFL Textbook For Seventh Grade. Journal Of English And Education.

Guilloteaux, M. J. (2013). Language Textbook Selection: Using Materials Analysis From The Perspective Of Sla Principles. 22, 231-239. https://doi.org/10.1007/S40299-012-0015-3

Halliday, M. A. . (1996). "Introduction", Language As Social Semiotic: The Social Interpretation Of Language And Meaning. In The Communication Theory Reader.

Harmer, J. (2001). Book Review : The Practice Of English Language Teaching. RELC Journal. https://doi.org/10.1177/003368820103200109

Holmes, J. (2013). An Introduction To Sociolinguistics. 4th Edition. In Pearson Education Limited. https://doi.org/10.1525/Jlin.2003.13.2.252

Innovation In English Language Teaching. (2013). In Innovation In English Language Teaching. https://doi.org/10.4324/9781315011561

Mertens, D. M. (2014). Research And Evaluation In Education And Psychology: Integrating Diversity With Quantitative, Qualitative, And Mixed Methods. Sage Publications.An Introduction To Research. https://doi.org/10.1038/46965

Michael, C. (2014). From Communicative Competence To Communicative Language Pedagogy. In Language And Communication. https://doi.org/10.4324/9781315836027-6

Nevendorf, K. A. (2020). The Content Analysis Guidebook. In The Content Analysis Guidebook. https://doi.org/10.4135/9781071802878

Nurjanah, I., \& Umaemah, A. (2019). An Analysis Of Cultural Content In The Textbook "Pathway To English" For Second Grade In Senior High School. ELT Echo: The Journal Of English Language Teaching In Foreign Language Context. https://doi.org/10.24235/Eltecho.V4i1.4536

Reinildis Atjna Cyntia Rynanta, S. R. (2018). Content Analysis On The English Textbook Entitled 'English In Mind Starter (Student'S Book)". State University Of Malang.

Savignon, S. J. (2002). Communicative Language Teaching: Linguistic Theory And Classroom Practice (Chp 1). Interpreting Communicative Language Teaching: Contexts And Concerns In Teacher Education. https://doi.org/10.1017/So272263104251051

Saville-Troike, M. (2008). The Ethnography Of Communication: An Introduction: Third Edition. In The Ethnography of Communication: An Introduction: Third Edition. https://doi.org/10.1002/9780470758373

Saville-Troike, M. (2009). The Ethnography Of Communication. In Sociolinguistics And Language Teaching. https://doi.org/10.1017/Cbog780511551185.017

Spolsky, B. (2010). Ferguson And Fishman: Sociolinguistics And The Sociology Of Language. In The SAGE Handbook Of Sociolinguistics. https://doi.org/10.4135/9781446200957.N1

Street, B., \& Leung, C. (2010). Sociolinguistics, Language Teaching And New Literacy Studies. In Sociolinguistics And Language Education. https://doi.org/10.21832/9781847692849-013

Suryani, R. W. (2018). "When English Rings The Bell": An English Textbook Analysis. English 
Language Teaching And Research, 2(1), 258-268. http://Ejournal.Unp.Ac.Id/Index.Php/Eltar/Article/View/102669/101056

Tambunan, M. S., Sipayung, K. T., \& Sinaga, N. T. (2019). Content Analysis Of English Textbook 'Interactive English' Used In First Grade Juniorhigh School In 2013 Curriculum. JETAL: Journal Of English Teaching \& Applied Linguistic, 1(1), 20-27. https://doi.org/10.36655/Jetal.V1i1.101

Tomlinson, B. (2012). Materials Development For Language Learning And Teaching. In Language Teaching. https://doi.org/10.1017/S0261444811000528

Vockell, E. L., \& Asher, W. (1989). Sources Of Information In Educational Research Literature. Journal Of Experimental Education. https://doi.org/10.1080/00220973.1989.10806523

Wardhaugh, R. (2006). An Introduction To Sociolinguistics Fifth Edition. In Blackwell Publishing. 